\title{
Ethanol Intake during Lactation Alters Milk Nutrient Composition and Growth and Mineral Status of Rat Pups
}

\author{
CÍNTIA R.P. AZARA ${ }^{1}$, INGRID C. MAIA ${ }^{1}$, CAROLINA N. RANGEL $^{1}$, \\ MÁRIO A.C. SILVA-NETO ${ }^{2}$, RENATA F.B.SERPA ${ }^{3}$, EDGAR F.O. DE JESUS ${ }^{3}$, \\ MARIA G. TAVARES DO CARMO ${ }^{1}$ and ELIANE FIALHO ${ }^{1 *}$
}

\author{
${ }^{1}$ Instituto de Nutrição Josué de Castro, Centro de Ciências da Saúde, Universidade Federal do Rio de Janeiro, \\ RJ, Brazil \\ ${ }^{2}$ Instituto de Bioquímica Médica, Programa de Biologia Molecular e Biotecnologia, Centro de Ciências da \\ Saúde, Universidade Federal do Rio de Janeiro, RJ, Brazil \\ ${ }^{3}$ Laboratório de Instrumentação Nuclear / COPPE, Universidade Federal do Rio de Janeiro, RJ, Brazil
}

\begin{abstract}
Lactating Wistar rats were fed a liquid diet containing either ethanol [ethanol-fed group (EFG)] or an isocaloric amount of carbohydrate [pair-fed group (PFG)] from day 1 postpartum up to day 14 of lactation, to investigate micro/macronutrient milk composition and the mineral status of pups. EFG presented a reduction of daily milk production and milk composition was significantly higher in protein and lower in carbohydrate, while the lipid content was similar to that of PFG. When compared to PFG, the milk of EFG had a decreased proportion of C22:6 n-3 fatty acid and an increase in medium-chain fatty acids and of several minerals. Pups of EFG showed reduced growth and a lower concentration of $\mathrm{Cu}$ and $\mathrm{Sr}$ in plasma and lower concentrations of $\mathrm{Ca}, \mathrm{P}$ and $\mathrm{Cl}$, and higher concentrations of $\mathrm{Cd}$ in the brain. We conclude that maternal EtOH intake greatly impairs lactational performance and modifies the mineral status of pups.
\end{abstract}

Key terms: breast milk, ethanol, rats, lactation, minerals status and milk composition.

\section{INTRODUCTION}

Alcoholism is considered a serious public health problem in Brazil (Burgos et al., 2004) that is more serious when occurring in pregnant and lactating women. Pregnant women are discouraged from drinking alcohol because of detrimental effects on fetal development. Nonetheless, in many cultures, including in Brazil, lactating women are encouraged to drink alcohol to optimize breast milk production (Blume, 1987; Mennella et al., 2005).
Ethanol (EtOH) (and possibly its products) can pass from the maternal circulation into breast milk. Mennella et al. (2005) have demonstrated that in human beings ethanol ingested through breast milk has adverse effects on the child. This study showed that babies drank less milk and had a three-hour-disturbed sleep-wake pattern after their nursing mothers consumed one to two standard drinks.

Studies using laboratory animals have demonstrated that administering EtOH to drinking water during pregnancy, and even

\footnotetext{
ABBREVIATIONS: AA - arachidonic acid; AIN-93G - American Institute of Nutrition; DHA docosahexaenoic acid; EFG - ethanol-fed group; EPA - eicosapentaenoic acid; eV - electron-volt; Ga - gallium; IP - intraperitoneal; keV - kilo electron-volt; mrad - mili roentgen absorbed dose; MUFA - monounsaturated fatty acid; PFG - pair-fed group; PUFA - polyunsaturated fatty acid; SFA - saturated fatty acid; TXRF - Total Reflection X-Ray Fluorescence.

* Corresponding author: Departamento de Nutrição Básica e Experimental, Instituto de Nutrição Josué de Castro, Centro de Ciências da Saúde, Universidade Federal do Rio de Janeiro, UFRJ, Caixa Postal 68041, Cidade Universitária, Ilha do Fundão, Rio de Janeiro, CEP 21941-590, Brasil. Telephone number + 55212562 6449. Fax number + 552125626695 . E-mail address: fialho@nutricao.ufrj.br
} 
earlier in the mother's life, can impair mammary gland development (Tavares do Carmo et al., 1996; Fuentes et al., 2001). These alterations can contribute to altering the production and nutritional composition of the milk. In fact, administering EtOH during pregnancy and lactation can alter the macronutrient composition of milk (Herrera, 1981; Heil et al., 1998; Tavares do Carmo et al., 1999; Albuquerque et al., 2000), and, therefore, the supply of nutrients for the pups, as milk is the only source of nutrients during this period, with consequences for their development. On the other hand, pregnancy and lactation are periods of high mineral requirements and there are few studies of the micronutrient status of milk, particularly of minerals associated with EtOH intake during lactation.

However, despite extensive investigation of postnatal ethanol exposure using lactating dams fed on ethanol liquid diets (Sanchis et al., 1989; Zhu and Seelig, 2000; Oyama and Oller Do Nascimento, 2003), there is a lack of information about the nutritional characteristics of milk, particularly micronutrients.

The present study sought to determine whether EtOH administration in a liquid diet during rat lactation affects the macro and micronutrient composition of the milk. The work was extended to determine brain and liver mineral status in suckling pups. The milk volume produced was also assessed in lactating rats.

\section{MATERIALS AND METHODS}

\section{Animals}

The Experimental Research Committee of the Universidade Federal do Rio de Janeiro approved all procedures involving animals.

Adult virgin female Wistar rats weighing 180 to $220 \mathrm{~g}$, approximately 90 days of age, were obtained from the animal breeding unit of the Instituto de Nutrição Josué de Castro, Universidade Federal do Rio de Janeiro, Rio de Janeiro State, Brazil. The rats were mated to obtain the first offspring.
On day 1 of lactation, animals were randomly divided into two groups: ethanolfed group (EFG) $n=10$ and pair-fed group (PFG) $n=10$ and placed in individual metabolic cages, on a 12-h light / 12-h dark cycle in a temperature and relative humidity-controlled room $\left(22^{\circ} \mathrm{C}-26^{\circ} \mathrm{C}\right.$ and $50 \%$, respectively).

\section{Experimental design}

Rats were pair-fed from days 1-14 of lactation, receiving a nutritionally adequate Lieber-DeCarli liquid diet formulated for the lactating period requirements of rodents, according to the American Institute of Nutrition (AIN) (Reeves et al., 1993), as the sole source of food (AIN 93G \#710301 for EFG and AIN 93G \#710079 for PFG; Dyets Inc., Bethlehem, PA, USA) (Table I). Diets contained 4.2 kilojoule per milliliter (19.7\% and $17.0 \%$ of total energy intake as protein and fat, respectively). Microelement amounts in both diets were largely above the recommendations for lactation, thus ensuring that the rats had sufficient intake of vitamins and minerals. The EFG received the liquid diet ad libitum, but maltose dextrose was substituted isocalorically by ethanol to provide $34 \%$ of the total energy (Table I).

The PFG received the isocaloric liquid diet without ethanol in a volume equal to that ingested by rats of the EFG. Liquid diets were renewed twice a day at 8:00 a.m. and 8:00 p.m., so the animals consumed ethanol continuously until the time they were killed. Daily fluid intake was measured throughout the treatment period (days 1-14 of lactation). Dams were weighed on days $0,4,8$, and 12 of lactation and pups on days $1,5,10$ and 14 , every morning at 08:00 a.m., on a digital balance (Coleman, PW- 1100 model).

\section{Milk, blood, liver and brain collection}

Milk samples were collected from dams on day 14 of lactation during the morning (Keen et al., 1981). After being separated from their litters for 4 hours, they were intraperitoneally injected with 5 units of oxytocin (Sandoz Products Ltda), and after 
15 minutes were anesthetized with ketamine $(100 \mathrm{mg} / \mathrm{Kg})$ and xylazine (16 $\mathrm{mg} / \mathrm{Kg}$ ). The milk was obtained by gentle hand stripping of the teat. After milking, dams were decapitated and blood collected in heparinized tubes. Plasma was obtained by centrifugation and aliquots were used to measure maternal mineral levels. Pups were decapitated; their brains and livers were removed and weighed, pooled for each litter, and then frozen in liquid nitrogen and kept at $-80^{\circ} \mathrm{C}$ until analysis.

\section{Milk production and analysis}

Milk yield was estimated from pup weight and weight gains on days 1-2, 7-8 and 12-13 of lactation, as described previously (Sampson and Jansen, 1984). Milk samples were obtained from day 14 of lactation. Milk samples were diluted 50 times with deionized water for the determination of milk carbohydrate and protein. For lipid analysis, the dilution factor used was 10 . For mineral and fatty acid determinations, integral milk was used. Carbohydrate determination was done by colorimetric method described by Dubois et al. (1956). Protein concentration was analyzed by the procedure of Lowry et al. (1951). The fat content of these samples was gravimetrically determined with petroleum ether, according to the method described by Godbole et al. (1981).

The energy value of the milk was calculated using the values of $4 \mathrm{Kcal} / \mathrm{g}$ for protein and lactose, and $9 \mathrm{Kcal} / \mathrm{g}$ for fat. The milk nutrient output of day 14 was estimated from the values of milk composition and corresponding milk production.

TABLE 1

Diet composition [grams per liter (g/L)]

\begin{tabular}{lcc}
\hline Ingredient & EFG $(\mathrm{g} / \mathrm{L})$ & PFG $(\mathrm{g} / \mathrm{L})$ \\
\hline Casein & 53.00 & 53.00 \\
L-cystine & 0.80 & 0.80 \\
Cellulose & 13.30 & 13.30 \\
Maltose dextrin & 43.30 & 135.40 \\
Ethanol (95\%)* & 65.40 & -- \\
Sucrose & 26.50 & 26.50 \\
Soybean oil (stabilizer T-butylhydroquinone) & 18.60 & 18.60 \\
Salt mix a & 9.28 & 9.28 \\
Vitamin mix & 2.65 & 2.65 \\
Choline bitartrate & 0.53 & 0.53 \\
Xanthan gum & 3.00 & 3.00
\end{tabular}

* ethanol is in $\mathrm{ml} / \mathrm{L}$.

${ }^{\text {a }}$ Contained the following $(\mathrm{g} / \mathrm{L})$ : calcium carbonate $=357.00$; potassium phosphate, monobasic $=196.00$; potassium citrate, $\mathrm{H}_{2} \mathrm{O}=70.78$; sodium chloride $=74.00$; potassium sulfate $=46.60$; magnesium oxide $=$ 24.00; ferrous sulfate, $7 \mathrm{H}_{2} \mathrm{O}=5.21$; zinc carbonate $=1.65$; manganous carbonate $=0.63$; cupric carbonate $=$ 0.30 ; potassium iodate $=0.01$; sodium selenate $=0.01025$; ammonium paramolybdate, $4 \mathrm{H}_{2} \mathrm{O}=0.00795$; sodiummetasilicate, $9 \mathrm{H}_{2} \mathrm{O}=1.45$; chromium potassium sulfate, $12 \mathrm{H}_{2} \mathrm{O}=0.275$; lithium chloride $=0.0174$; boric acid $=0.0815 ;$ sodium fluoride $=0.0635 ;$ nickel carbonate $=0.0318 ;$ ammonium vanade $=0.0066$; and sucrose, finely powdered $=221.87$.

${ }^{\mathrm{b}}$ Contained the following $(\mathrm{g} / \mathrm{L})$ : niacin $=3.00$; calcium pantothenate $=1.60 ;$ pyridoxine hydrochloride $=0.70$; thiamine hydrochloride $=0.60$; riboflavin $=0.60$; folic acid $=0.20$; biotin $=0.02$; vitamin E acetate $(500 \mathrm{IU} /$ $\mathrm{g})=15.00$; vitamin B12 $(0.1 \%)=2.50$; vitamin A palm $(500.000 \mathrm{IU} / \mathrm{g})=0.80 ;$ vitamin $\mathrm{D} 3(400.000 \mathrm{IU} / \mathrm{g})=$ 0.25 ; vitamin $\mathrm{K} 1$ premix $(10 \mathrm{mg} / \mathrm{g})=7.50$; and sucrose $=967.23$. 


\section{Fatty acid determination}

Lipid extraction, saponification, and methylation of fatty acids in milk were performed in duplicate from a $200 \mu \mathrm{L}$ sample of milk according to the method of Lepage and Roy (1986), which recommends treatment with $2 \mathrm{~mL}$ of $4: 1(\mathrm{v} / \mathrm{v})$ methanol:benzene solution, and addition of $200 \mu \mathrm{L}$ of acetyl chloride under light agitation. Fatty acid methyl esters were measured in a Perkin Elmer chromatography autosystem provided with a hydrogen flame ionization detector and a capillary column $(60 \mathrm{~m}$ x $0.30 \mathrm{~mm}$ i.d.), packed with 10\% SP 2330 (Supelco Inc, Bellefonte, PA, USA) as a stationary phase. Nitrogen was used as a carrier gas. Injection and detection temperatures were both at $220^{\circ} \mathrm{C}$, whereas oven temperature was programmed to vary $5^{\circ} \mathrm{C} / \mathrm{min}$ from 40 to $225^{\circ} \mathrm{C}$. Esters were identified comparing retention times with known standards (Sigma Aldrich, St Louis, MO, USA), and quantification was done by calculating peak areas with an integrator. Results were expressed as a weight percentage $(\mathrm{g} / 100 \mathrm{~g}$ total fatty acids).

\section{Mineral determination}

The levels of minerals were determined by total reflection X-ray fluorescence analysis (TXRF) with synchrotron radiation. The samples (milk, brain, liver and plasma) were thawed and homogenized, using a vortex shaker prior to sub sampling. $0.5 \mathrm{~mL}$ of each sample was transferred to polyethylene vials free of trace elements, and treated with $0.5 \mathrm{~mL}$ of $\mathrm{HNO}_{3}$ and $0.5 \mathrm{~mL}$ of $\mathrm{H}_{2} \mathrm{O}_{2}$ at $110^{\circ} \mathrm{C}$ for 24 hours, with the vials sealed. After this, the solution was left to dry and the volume recovered to $0.5 \mathrm{~mL}$ with a solution of $\mathrm{HNO}_{3} 0.1 \mathrm{M}$ as a diluting agent. A $50 \mathrm{~mL}$ of solution $(40 \mathrm{mg} / \mathrm{g} \mathrm{Ga})$ of gallium $(\mathrm{Ga}) \mathrm{F}$ was added to the sample, which was used as an internal standard of reference for the TXRF measurements in order to obtain a concentration of $10 \mathrm{ppm}$ of $\mathrm{Ga}$ in the solution. A $5 \mathrm{~mL}$ aliquot of the solution was placed on a Perspex sample support using a pipette, and subsequently submitted to drying in a vacuum dryer for 3 hours, obtaining spots of approximately $5 \mathrm{~mm}$ in diameter. Measurement of the samples by TXRF was carried out at the National Laboratory of Synchrotron Light (LNLS), Campinas, São Paulo State, Brazil. All samples were processed in duplicate, and the final values were taken as the means of the results, obtained by running each sample three times. A white beam of irradiation with a maximum energy of 20 $\mathrm{keV}$ altered by $0.5 \mathrm{~mm}$ of aluminum, with an angle of incidence of $1.0 \mathrm{mrad}$, was utilized to excite the sample. The characteristic $X$ rays were detected by a silicon-lithium ( $\mathrm{Si}-\mathrm{Li}$ ) detector with a resolution of $165 \mathrm{eV}$ for $5.9 \mathrm{keV}$ energy, linked to an electronic system with a multichannel analyzer (Canberra). The distance between the detector and sample was fixed at $6.0 \mathrm{~mm}$, using a tantalum (Ta) collimator with an aperture of $1.0 \mathrm{~mm}$ in order to limit the dead time of the measurements to a minimum value of $15 \%$. The spectrometer sensitivity was determined using multi-element standards with different concentrations containing $\mathrm{Al}$, $\mathrm{Si}, \mathrm{Ca}, \mathrm{Ti}, \mathrm{Cr}, \mathrm{Fe}, \mathrm{Ni}, \mathrm{Zn}, \mathrm{Ga}$, and Se. The standards were prepared from monoelemental solutions (induced coupled plasma (ICP), supplied by Sigma (St. Louis, MO, USA). The accuracy of the measurements was calculated by determining the concentration of the elements of a standard solution (ICP-multielement standard solution FMERCK). The measurement time was $300 \mathrm{~s}$ for the samples and $150 \mathrm{~s}$ for the standards. The spectrums were analyzed by a quantitative analysis program (quantitative X-ray analysis system FQXAS) distributed by the International Atomic Energy Agency (IAEA), which gives the fluorescent count intensities for each element and the associated uncertainty (Klockenkämper, 1992).

\section{Statistical analysis}

Results were expressed as mean \pm SEM. Differences between means were tested for significance by Student's t test. Differences between groups were considered statistically significant when $\mathrm{p}<0.05$ or $\mathrm{p}<0.001$. 


\section{RESULTS}

Alcohol intake and body mass change of dams

In the present study, EtOH was administered in the liquid diet for 14 days (postnatal days 1-14) of lactating rats, resulting in a daily ethanol intake of between 12.8 and $14.9 \mathrm{~g} / \mathrm{Kg}$, and a blood ethanol concentration of $25 \mathrm{mM}$ (data not shown). Dams looked healthy and gained weight throughout the feeding period. The corporal mass of the mothers showed no significant difference $(p>0.05)$ between EFG and its respective PFG during the first 14 days of lactation (data not shown).

\section{Milk production and pup weight gain}

Figure 1A shows the milk production of the females of EFG and PFG during days 1-2, 6-7, 9-10, and 13-14 of lactation. After day 7 until day 14 of lactation, the lactating female rats that ingested ethanol had a lower production of milk in relation to the values of PFG $(p<0.001)$. The values of milk production on day 14 of lactation were $2.42 \pm 0.2 \mathrm{~mL} /$ day from $\mathrm{PFG}$, and $1.76 \pm$ $0.01 \mathrm{~mL} /$ day from EFG $(\mathrm{p}<0.001)$. The body mass of pups nursed by the two groups of dams is shown in Figure 1B. From day 11 on, the pups from the EFG did not maintain the same profile of body weight gain compared to those from the PFG. The reduced milk production of ethanol-treated mothers was associated with a significant reduction in corporal mass gain of their pups and these differences became more evident as the lactating period advanced (Figure 1B).

\section{Milk macronutrient composition}

Milk composition and the estimated milk macronutrient output on day 14 of the two experimental groups are shown in Table II. Ethanol-treated mothers produced milk with significantly less carbohydrates and more protein concentrations $(\mathrm{p}<0.05)$, whereas the lipid content was unaffected.

The macronutrients were also calculated in agreement with the production of milk for 24 hours on days 12-14 of lactation, characterized as the peak period of lactation. We observed a smaller concentration of proteins and carbohydrates and a greater concentration of lipids in the EFG milk compared to that of the PFG group, with significant difference $(p<0.05)$.

It was also observed that the energetic value of the EFG milk presented values significantly higher $(\mathrm{p}<0.05)$.

Regarding the fatty acid profile in dam milk on day 14 of lactation, the proportion of medium-chain fatty acids (C10:0 and C12:0), C18:0, 16:1 n-7 and 18:1 n-9 in milk was significantly higher in EFG than in PFG. The proportion of other fatty acids, including linoleic acid (18:2 n-6) and a-linolenic acid (18:3n-3), was similar in both groups. Futhermore, a low proportion of DHA (22:6 n-3) was observed in milk from ethanol-treated dams as compared to that of the PFG $(\mathrm{p}<0.05)$. (Table III).

\section{Milk micronutrient composition}

The effects of maternal ethanol intake on milk mineral concentration are presented in Table IV. The ethanol-treated mothers produced milk with increased concentrations of several minerals, such as $\mathrm{Ca}(64 \%), \mathrm{P}(45 \%), \mathrm{S}(42 \%), \mathrm{K}(149 \%), \mathrm{Cl}$ (227\%), Zn (38.8\%), Cu (91\%), Sr (27\%), $\mathrm{Cr}(76 \%), \mathrm{Mn}(80 \%)$, Se (152\%), Ni (56\%) in relation to PFG $(\mathrm{p}<0.05$ or $\mathrm{p}<0.001)$. The milk Fe levels were similar in both groups studied. When the concentrations of these minerals present in the milk output on day 14 of lactation were examined, we observed that all minerals were similar in quantities between the groups, but $\mathrm{Cl}$ and $\mathrm{Se}$ displayed values $114 \%$ and $86 \%$ higher in EFG compared to PFG.

Plasma mineral concentration in dams and pups

Table V presents the average concentration of minerals in the plasma of mothers and pups of both groups. Phosphate (P) and ferrous ( $\mathrm{Fe})$ displayed lower concentrations, and bromine $(\mathrm{Br})$ 


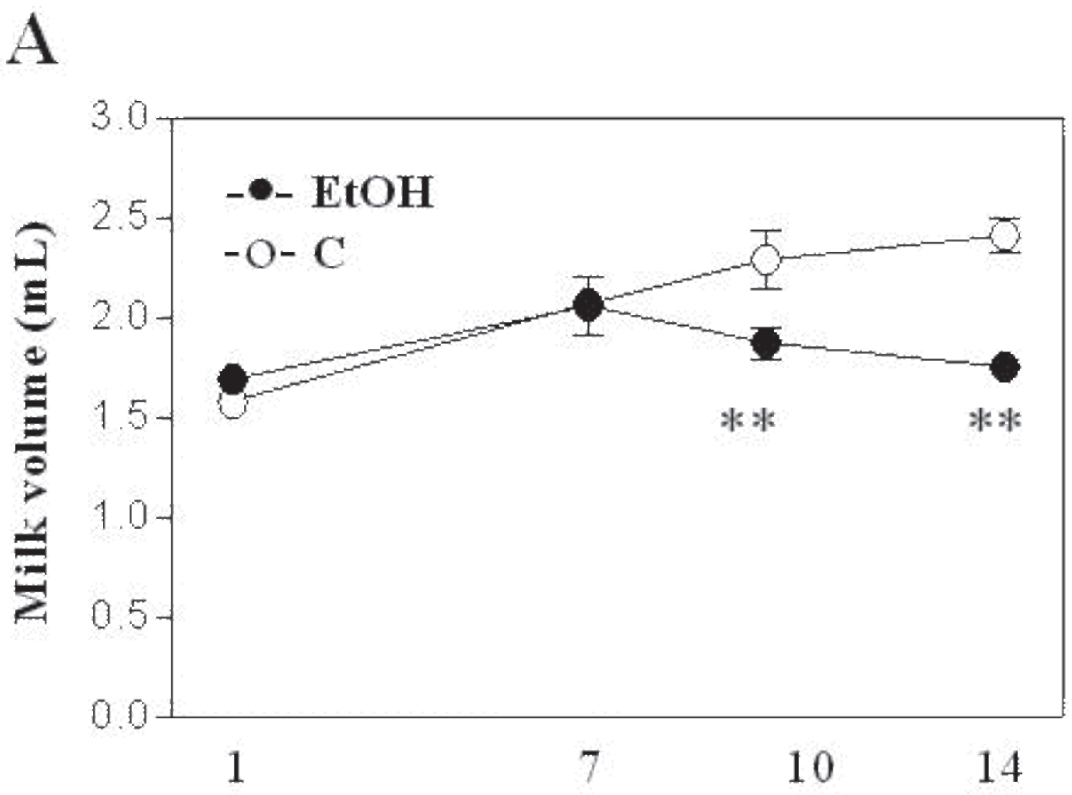

Days of lactation

B

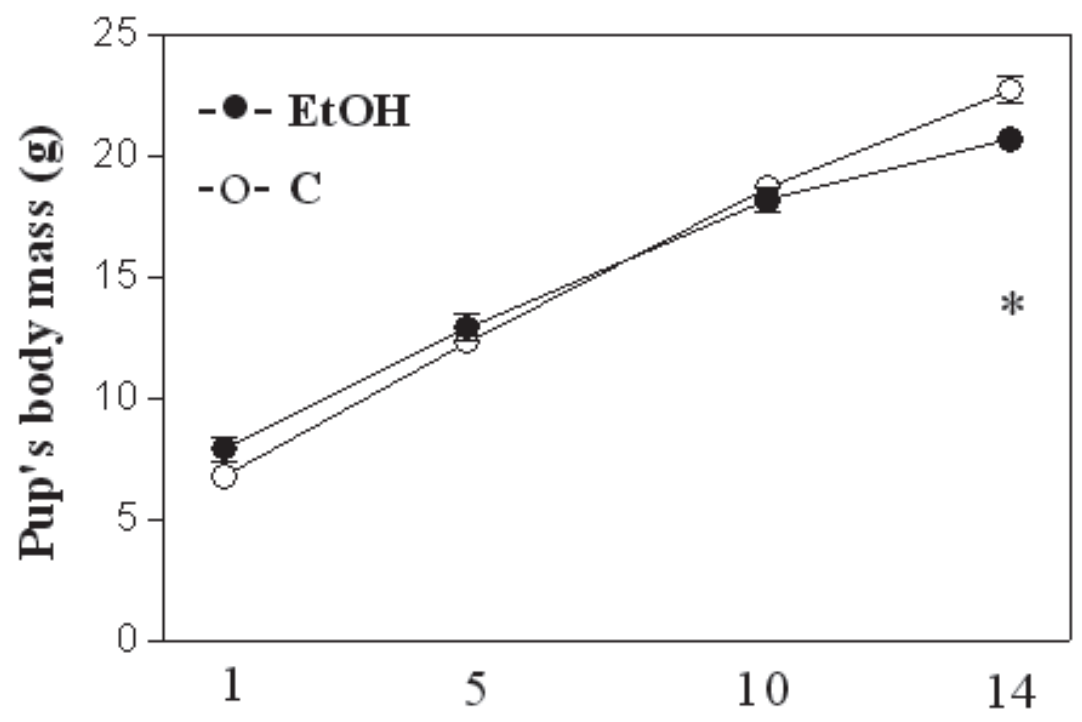

\section{Days of life}

Figure 1: Effect of ethanol intake on milk production and pup body mass during 14 days of lactation. The production of milk was determined in controls and ethanol-treated female rats according to the technique described by Sampson and Jansen (1984). Milk production (Panel A) and pup body mass (Panel B) from each group were estimated as described in the Materials and Methods section. The symbols are -O- PFG; - $\bullet$ EFG. Values are mean \pm SEM from triplicate at three independent experiments with 8-10 animals per group. * Significantly different at $\mathrm{p}<0.05$ and ** significantly different at $\mathrm{p}<0.001$. 
showed higher concentrations in the plasma of EFG dams compared to that of PFG. Despite these differences, the concentration of other minerals was similar in both groups of dams. In suckling pups from ethanol-treated mothers a lower concentration of $\mathrm{Cu}$ and Sr was observed in plasma (Table V). The other minerals did not present significant change.

\section{Liver and brain mineral status of pups}

As observed in Table VI, the mineral concentrations in the liver did not differ between the two groups. In the brain, we observed that $\mathrm{Ca}$ and $\mathrm{Cl}$ concentrations were significantly lower in pups from ethanoltreated mothers compared to those from PFG. Moreover, a higher concentration of $\mathrm{Cd}$ was observed in the brain from EFG.

TABLE 2

Effect of ethanol intake by lactating rats on milk macronutrient composition (expressed by $\mathrm{mL}$ or day production) and energetic value (Kcal/100 $\mathrm{mL})$.

The values were obtained from the milk of day 14 of lactation.

\begin{tabular}{lccccc}
\hline Macronutrients/ & \multicolumn{2}{c}{ Milk $(\mathrm{mL}$ production $)(\mu \mathrm{g} / \mathrm{mL})$} & & \multicolumn{2}{c}{ Milk (day production) $(\mu \mathrm{g} / \mathrm{day})$} \\
\cline { 2 - 3 } \cline { 5 - 6 } Energetic value & $\mathrm{C}$ & $\mathrm{EtOH}$ & & $\mathrm{C}$ & EtOH \\
\hline Protein & $12.17 \pm 0.12(23.4 \%)$ & $14.53 \pm 0.17 * *(28.1 \%)$ & $29.46 \pm 0.29(28.9 \%)$ & $25.57 \pm 0.31 * *(23.1 \%)$ \\
Lipid & $16.14 \pm 0.71(69.8 \%)$ & $15.31 \pm 0.41(66.7 \%)$ & & $28.41 \pm 0.9(62.8 \%)$ & $36.97 \pm 1.25 * *(72.6 \%)$ \\
Carbohydrate & $3.51 \pm 0.09(6.8 \%)$ & $2.73 \pm 0.05^{*}(5.2 \%)$ & & $8.50 \pm 0.21(8.3 \%)$ & $4.80 \pm 0.10 * *(4.3 \%)$ \\
$\begin{array}{l}\text { Energetic value } \\
(\text { Kcal/100mL) }\end{array}$ & $202.90 \pm 3.22$ & $212.10 \pm 3.76$ & & $407.10 \pm 10.86$ & $459.70 \pm 8.53 *$ \\
\hline
\end{tabular}

Values are mean \pm SEM of 8-10 samples. EtOH- Ethanol-fed group; C - Pair-fed group.

* Significantly different from $\mathrm{C}$ at $\mathrm{p}<0.05$.

** Significantly different from $\mathrm{C}$ at $\mathrm{p}<0.001$.

TABLE 3

Composition percentage (\%) of fatty acids in the milk of dams treated with ethanol and control diet in 14-day-old pups

\begin{tabular}{lcc}
\hline Fatty acids & $\mathrm{C}$ & EtOH \\
\hline C $10: 0$ & $2.82 \pm 0.09$ & $4.17 \pm 0.12^{* *}$ \\
C $12: 0$ & $4.04 \pm 0.01$ & $6.80 \pm 0.06^{* *}$ \\
C $14: 0$ & $18.90 \pm 1.03$ & $19.48 \pm 1.08$ \\
C $16: 0$ & $23.25 \pm 1.85$ & $20.75 \pm 1.04$ \\
C $18: 0$ & $3.87 \pm 0.36$ & $5.30 \pm 0.48^{*}$ \\
C $16: 1 n-7$ & $0.97 \pm 0.03$ & $1.77 \pm 0.08^{*}$ \\
C $18: 1 n-9$ & $17.95 \pm 1.02$ & $21.05 \pm 0.91^{*}$ \\
C $18: 2 n-6$ & $19.06 \pm 1.25$ & $18.02 \pm 1.69$ \\
C $18: 3 n-3$ & $1.04 \pm 0.04$ & $1.06 \pm 0.08$ \\
C $20: 4(\omega-6)$ AA & $1.13 \pm 0.07$ & $1.12 \pm 0.09$ \\
C $22: 6(\omega-3)$ DHA & $1.03 \pm 0.08$ & $0.55 \pm 0.01^{*}$ \\
\hline
\end{tabular}

Values are mean \pm SEM of 8 samples. EtOH- Ethanol-fed group; C - Pair-fed group AA, arachidonic acid; DHA - Docosahexaenoic acid.

${ }^{*}$ Significantly different from $\mathrm{C}$ at $\mathrm{p}<0.05$.

${ }^{* *}$ Significantly different from $\mathrm{C}$ at $\mathrm{p}<0.001$. 
TABLE 4

Effect of ethanol intake by lactating rats on milk mineral concentration on day 14 of lactation

\begin{tabular}{lccccc}
\hline \multirow{2}{*}{ Minerals } & \multicolumn{2}{c}{ milk $(\mu \mathrm{g} / \mathrm{mL}$ production $)$} & & \multicolumn{2}{c}{ milk $(\mu \mathrm{g} /$ day production $)$} \\
\cline { 2 - 3 } \cline { 5 - 6 } & $\mathrm{C}$ & $\mathrm{EtOH}$ & & $\mathrm{C}$ & EtOH \\
\hline $\mathbf{C a}$ & $2915.71 \pm 245.08$ & $4793.68 \pm 419.86^{*}$ & & $7055.88 \pm 593.13$ & $8438.95 \pm 738.54$ \\
$\mathbf{P}$ & $543.93 \pm 30.15$ & $790.74 \pm 62.44^{*}$ & & $1303.56 \pm 94.33$ & $1310.71 \pm 113.49$ \\
$\mathbf{S}$ & $542.00 \pm 36.28$ & $768.66 \pm 53.74^{*}$ & & $1311.58 \pm 87.79$ & $1352.81 \pm 94.57$ \\
$\mathbf{K}$ & $192.67 \pm 18.92$ & $480.04 \pm 46.18^{*}$ & & $661.84 \pm 60.24$ & $844.56 \pm 81.25$ \\
$\mathbf{C l}$ & $30.46 \pm 2.26$ & $99.68 \pm 9.94^{* *}$ & & $78.52 \pm 6.74$ & $175.65 \pm 17.51^{* *}$ \\
$\mathbf{Z n}$ & $10.06 \pm 0.70$ & $13.96 \pm 1.12^{*}$ & & $21.88 \pm 0.51$ & $24.55 \pm 1.98$ \\
$\mathbf{F e}$ & $5.81 \pm 0.37$ & $6.97 \pm 0.33$ & & $14.07 \pm 0.91$ & $12.26 \pm 0.58$ \\
$\mathbf{C u}$ & $1.84 \pm 0.17$ & $3.52 \pm 0.15^{* *}$ & & $5.38 \pm 0.53$ & $6.19 \pm 0.27$ \\
$\mathbf{S r}$ & $0.62 \pm 0.04$ & $0.79 \pm 0.07^{*}$ & & $1.50 \pm 0.10$ & $1.39 \pm 0.12$ \\
$\mathbf{C r}$ & $0.25 \pm 0.02$ & $0.44 \pm 0.01^{* *}$ & & $0.62 \pm 0.06$ & $0.78 \pm 0.02$ \\
$\mathbf{M n}$ & $0.20 \pm 0.01$ & $0.36 \pm 0.03^{*}$ & & $0.59 \pm 0.05$ & $0.63 \pm 0.05$ \\
$\mathbf{S e}$ & $0.03 \pm 0.00$ & $0.08 \pm 0.00^{* *}$ & & $0.07 \pm 0.00$ & $0.14 \pm 0.00^{* *}$ \\
$\mathbf{N i}$ & $0.09 \pm 0.01$ & $0.14 \pm 0.01^{*}$ & & $0.19 \pm 0.00$ & $0.24 \pm 0.01$ \\
\hline
\end{tabular}

Values are mean \pm SEM of 6-8 samples. EtOH- Ethanol-fed group; C - Pair-fed group.

* Significantly different from $\mathrm{C}$ at $\mathrm{p}<0.05$.

** Significantly different from $\mathrm{C}$ at $\mathrm{p}<0.001$.

TABLE 5

Effect of ethanol intake by lactating rats on the plasma mineral concentration on pups and dams on day 14 of lactation

\begin{tabular}{|c|c|c|c|c|}
\hline \multirow[t]{2}{*}{ Minerals } & \multicolumn{2}{|c|}{ dams $(\mu \mathrm{g} / \mathrm{mL})$} & \multicolumn{2}{|c|}{ pups $(\mu \mathrm{g} / \mathrm{mL})$} \\
\hline & $\mathrm{C}$ & EtOH & $\mathrm{C}$ & $\mathrm{EtOH}$ \\
\hline $\mathbf{C a}$ & $89.97 \pm 13.78$ & $76.01 \pm 4.03$ & $87.86 \pm 2.96$ & $90.40 \pm 2.69$ \\
\hline $\mathbf{P}$ & $58.23 \pm 3.23$ & $44.67 \pm 4.52 * *$ & $110.48 \pm 6.32$ & $110.22 \pm 6.03$ \\
\hline $\mathbf{S}$ & $553.52 \pm 28.30$ & $516.78 \pm 24.86$ & $494.03 \pm 14.69$ & $459.83 \pm 9.96$ \\
\hline $\mathbf{K}$ & $179.77 \pm 12.16$ & $160.30 \pm 9.82$ & $289.39 ” \pm 23.48$ & $282.85 \pm 23.31$ \\
\hline Cl & $1462.86 \pm 62.76$ & $1478.29 \pm 50.79$ & $1742.52 \pm 94.05$ & $1521.06 \pm 61.10$ \\
\hline $\mathbf{Z n}$ & $1.52 \pm 0.11$ & $1.49 \pm 0.05$ & $2.32 \pm 0.06$ & $2.42 \pm 0.09$ \\
\hline $\mathrm{Fe}$ & $4.30 \pm 0.39$ & $3.04 \pm 0.24 *$ & $1.95 \pm 0.16$ & $2.72 \pm 0.29$ \\
\hline $\mathbf{C u}$ & $0.97 \pm 0.03$ & $1.22 \pm 0.18$ & $0.46 \pm 0.03$ & $0.33 \pm 0.01 *$ \\
\hline $\mathbf{S r}$ & $0.17 \pm 0.01$ & $0.16 \pm 0.02$ & $0.07 \pm .0 .01$ & $0.05 \pm 0.01 * *$ \\
\hline $\mathrm{Cr}$ & ND & ND & ND & ND \\
\hline Mn & $0.059 \pm 0.00$ & $0.06 \pm 0.00$ & $0.05 \pm 0.00$ & $0.07 \pm 0.01$ \\
\hline Se & $0.24 \pm 0.01$ & $0.23 \pm 0.01$ & $0.10 \pm 0.01$ & $0.09 \pm 0.01$ \\
\hline $\mathrm{Br}$ & $1.59 \pm 0.04$ & $1.90 \pm 0.02 *$ & $3.40 \pm 0.18$ & $3.42 \pm 0.15$ \\
\hline $\mathbf{N i}$ & $0.01 \pm 0.00$ & $0.01 \pm 0.00$ & $0.02 \pm 0.00$ & $0.02 \pm 0.00$ \\
\hline
\end{tabular}

Values are mean \pm SEM of 6-8 samples. EtOH- Ethanol-fed group; C - Pair-fed group.

ND - Not determined

* Significantly different from $\mathrm{C}$ at $\mathrm{p}<0.05$.

** Significantly different from $\mathrm{C}$ at $\mathrm{p}<0.001$. 
TABLE 6

Effect of ethanol intake by lactating rats on the liver and brain mineral concentration $(\mathrm{mg} / \mathrm{g})$ of pups on day 14 of lactation

\begin{tabular}{lccccc}
\hline Minerals & \multicolumn{2}{c}{ liver $(\mu \mathrm{g} / \mathrm{g})$} & & \multicolumn{2}{c}{ brain $(\mu \mathrm{g} / \mathrm{g})$} \\
\cline { 2 - 3 } \cline { 5 - 6 } Ca & PFG & EFG & & PFG & EFG \\
\hline $\mathbf{P}$ & $0.19 \pm 0.003$ & $0.18 \pm 0.016$ & & $3.42 \pm 0.370$ & $1.07 \pm 0.550^{*}$ \\
$\mathbf{S}$ & $3.12 \pm 0.002$ & $3.03 \pm 0.001$ & & $8.65 \pm 1.110$ & $4.56 \pm 0.140^{*}$ \\
$\mathbf{C l}$ & $2.44 \pm 0.003$ & $2.53 \pm 0.003$ & & $4.53 \pm 0.580$ & $3.46 \pm 0.120$ \\
$\mathbf{Z n}$ & $0.73 \pm 0.005$ & $0.70 \pm 0.001$ & & $1.88 \pm 0.230$ & $1.18 \pm 0.050^{*}$ \\
$\mathbf{F e}$ & $0.04 \pm 0.005$ & $0.03 \pm 0.001$ & & $0.05 \pm 0.007$ & $0.03 \pm 0.003$ \\
$\mathbf{C u}$ & $0.05 \pm 0.002$ & $0.06 \pm 0.006$ & & $0.11 \pm 0.010$ & $0.06 \pm 0.003$ \\
$\mathbf{S r}$ & $0.04 \pm 0.003$ & $0.03 \pm 0.003$ & & $0.02 \pm 0.004$ & $0.01 \pm 0.001$ \\
$\mathbf{C r}$ & $\mathrm{ND}$ & $\mathrm{ND}$ & & $\mathrm{ND}$ & $\mathrm{ND}$ \\
$\mathbf{M n}$ & $0.01 \pm 0.001$ & $0.01 \pm 0.001$ & & $0.03 \pm 0.010$ & $0.03 \pm 0.010$ \\
$\mathbf{S e}$ & $0.03 \pm 0.002$ & $0.03 \pm 0.002$ & & $0.07 \pm 0.060$ & $0.04 \pm 0.005$ \\
$\mathbf{C d}$ & $0.01 \pm 0.002$ & $0.01 \pm 0.001$ & & $0.02 \pm 0.005$ & $0.01 \pm 0.005$ \\
\hline
\end{tabular}

Values are mean \pm SEM of 6-8 samples. EFG- Ethanol-fed group; PFG - Pair-fed group.

ND - Not determined

* Significantly different from PFG at $\mathrm{p}<0.05$.

** Significantly different from PFG at $\mathrm{p}<0.001$.

\section{DISCUSSION}

In the present study, EtOH was administered in the liquid diet for 14 days (postnatal days 1-14) to lactating rats, resulting in a daily ethanol intake between 12.8 and $14.9 \mathrm{~g} / \mathrm{Kg}$, and a blood ethanol concentration of $25 \mathrm{mM}$ (data not shown). In addition, the analysis of maternal body weight has not revealed significant differences between the EFG and the PFG, demonstrating that ethanol intake in this work has not resulted in nutritional alterations that could lead to changes in the weight gain of lactating rats. Besides, rats from both groups ingested energy and nutrient amounts within the nutritional requirements for lactating rats, according to the AIN (Reeves et al., 1993). Peres et al. (2004), administering alcoholic liquid diet during gestation, showed that there was no significant difference between the groups regarding dietary consumption and body weight during the whole experimental period. Thus, based on the available literature, and also according to our results of ethanol intake and nutritional status of mothers, the experimental model of the present study showed that the deleterious effects of ethanol intake are not derived from the malnutrition caused by it.

It is known that after 30 minutes of ethanol ingestion it is already present in the maternal milk and it modifies the sensorial characteristics of the milk even in low concentrations (Mennella and Beauchamp, 1993, Subramanian et al., 1999, Lima et al., 2002; Burgos et al., 2004). This process also leads to a reduced suction of the pups and consequent decrease of the hormone levels responsible for the synthesis and ejection of the milk (Tucker, 1979; Vilaró et al., 1987; Whitworth, 1988; Subramanian, 1999). Analyzing the results of Figure 1A, we can conclude that the ethanol intake caused a reduction in milk production, starting on day 7 of lactation. According to the literature cited, it was probably due to a decrease in the levels of the hormones prolactin and oxytocin, responsible, respectively, for the synthesis and ejection of the milk. On the other hand, 
probably, part of this effect relates to the endocrine effects of ethanol consumption that involves inhibition of antidiuretic hormone release, thus impairing the water balance with changes in milk volume and composition, although these effects are more frequent when ethanol was added to the drinking fluid (Jones et al., 1981; Marquis et al., 1984; Testar et al.,1986).

In addition, it is not possible in most experiments to separate the effects of alcohol from those caused by its metabolic product, acetaldehyde. Thus, whether or not these effects of alcohol impairing milk production could be caused by acetaldehyde instead of ethanol is a subject for more investigations, since there were no adequate reports found in the literature. In lactating rats, Guerri and Sanchis (1986) have observed that acetaldehyde levels in milk were always $35-45 \%$ lower than in blood, and Kesaniemi (1974), with lactating women, showed that acetaldehyde, the toxic metabolite of alcohol, does not appear to pass to breast milk.

In relation to alteration in milk production in EFG, we observed a decrease in pup growth, mostly at the lactation peak (days 12-14 of lactation). This is the maximum milk production period in rats (Figure 1B), suggesting that this effect might be a consequence of the ethanol intake by the dams, producing less milk than their capacity and not matching the milk requirements of the pups, thus impairing pup growth. These results agree with those of other investigators using other experimental models for administration of ethanol during pregnancy and/or lactation (Vilaró et al., 1987; Tavares do Carmo et al., 1999; Heil and Subramanian, 2000).

Rat pups (Molina et al., 2007) and human infants (Faas et al., 2000; Mennella and Beauchamp, 1993; Mennella, 1997) seem capable of processing ethanol present in the milk during the nursing period. In another study, Pueta et al, 2008 observed that intoxication during nursing disrupted the capability of the dam to retrieve the pups and to adopt a crouching posture. On the other hand, the consumption of a single dose of alcoholic beer by nursing mothers flavored their milk and decreased the amount of milk consumed by their infants (Mennella and Beauchamp, 1993). All these factors may have functional consequences for milk yield and milk composition, with a negative impact on growth rates of offspring.

In addition to the effect of alcohol impairing milk production, we observed that ethanol in the liquid diet also affected milk composition. When compared to PFG, EFG presented similar milk lipid concentrations, with significantly less carbohydrates and higher protein concentration. Vilaró et al. (1987) observed decreased lactose and increased triglyceride concentration in milk of ethanol-treated rats. Brigham et al. (1992), using another experimental model, suggested that this is an expected finding because carbohydrate concentration is positively associated with milk volume, whereas protein concentration is not. Aditionally, the possibility that ethanol can reduce glucose production through the gluconeogenic pathway cannot be discarded. This could contribute to diminishing the carbohydrate abundance of milk (Sumida et al., 2007). Finally, it is also possible that lower carbohydrate concentration in the EFG milk reflects the reduction of lactose synthesis in the mammary gland, due to a probable deviation of the carbohydrates for lipid synthesis in this tissue. This hypothesis seems to be valid, since other studies have shown that maternal intake of ethanol during the first 12 days of lactation enhanced the mammary gland lipogenesis (Tavares do Carmo et al., 1996), and enhanced the mammary gland uptake of circulating fatty acid triglycerides due to augmented lipoprotein lipase activity (Vilaró et al., 1987). The fatty acid profile in milk of ethanol-treated rats in this study may also be a consequence of the effects shown by these authors. The proportion of medium-chain fatty acids (C10:0 and C12:0) was higher in EFG when compared to $\mathrm{PFG}$, which would indicate a specific abundance of these lipogenic products in the mammary gland of ethanol-treated rats. Since it is known that triglycerides containing medium-chain fatty acids are more easily hydrolyzed and absorbed 
during suckling than long-chain fatty acids (Neville and Picciano, 1997; GenzelBoroviczény et al., 1997), the preservation of those fatty acids in milk of ethanoltreated lactating mothers may well be a metabolic adaptation addressed to guarantee offspring survival, even when the amount of available milk is not sufficient. According to this, although the ethanoltreated dams produced less milk than controls, the volume measurement and the macronutrient analysis of the milk on day 14 resulted in a higher energy content in the milk of the ethanol-treated rats (Table II), this being possible because the energetic value of lipids is greater than that of protein and carbohydrates.

DHA is essential for the growth and functional development of the brain in infants (Marszalek and Lodish, 2005). The proportional increments in $\mathrm{C} 18: 1, \mathrm{C} 16: 1$ and $\mathrm{C} 18: 0$, and the decrease in $\mathrm{C} 22: 6$ n-3 in milk found in the present study in the EFG are probably the result of ethanol action on fatty acid metabolism. Ethanol is known to inhibit both $\Delta 6$-desaturase and $\Delta 5$ desaturase activities (Nervi et al., 1980) which are responsible for the conversion of dietary linoleic acid (18:2 n-6) and alphalinolenic (18:3 n-3) to their respective metabolites, arachidonic acid (20:4 n-6) and docosahexaenoic acid (DHA, 22:6n-3). Thus, these inhibitory effects of ethanol on the activity of these enzymes may be responsible for the decrease in the C22:6 n3 fatty acid found here in milk of the ethanol-treated lactating rats.

To our knowledge, this is the first report of the profile of several minerals in milk from lactating rats receiving ethanol in liquid diets. In the present study, for mineral analysis, we used the Total Reflection X-Ray Fluorescence (TXRF) technique. This is an extremely useful tool in mineral determination. Its main advantages over other methods are the low detection limits and the simultaneous determination of several elements, employing small amounts of sample (Klockenkämper, 1992). This latter characteristic is extremely important considering the small amount of milk that can be collected from rats in each experiment (1-2mL/rat). The procedure used for measuring the mineral content of the rat milk samples provided information on the total quantity of minerals. We could not partition the ions between their diffusible and non-diffusible pools. The results reported can therefore only represent the total ion content of the milk.

Present results show that ethanol treatment affects milk mineral composition. Ethanol-treated mothers presented an increase in the concentration of several minerals, such as $\mathrm{Ca}, \mathrm{P}, \mathrm{S}, \mathrm{K}, \mathrm{Cl}, \mathrm{Zn}, \mathrm{Cu}, \mathrm{Sr}$, $\mathrm{Cr}, \mathrm{Mn}, \mathrm{Se}$, and $\mathrm{Ni}$ in relation to PFG (Table IV). These results suggest an adaptative increase in some elements. On the other hand, the mechanisms of the divergent responses between EFG and PFG diets could not be ascertained from the present results. The possible hypothesis would be: (a) Since milk salts exist primarily as either ions in solution, bound to protein or associated with casein micelles, they are concentrated in the milk aqueous phase, and (b) Variations in the milk lipid content will therefore dilute the ion concentration in whole milk and possibly mask any changes in ion concentration associated with the aqueous phase. It is therefore worth considering the possible effects of ethanol intake on the ion concentration of fat-free milk (FFM) in future studies.

Another explanation for this increase in the mineral concentration in the EFG milk would be an increase of bioavailability of a trace element for the mammary gland of EFG (probably due to the high mobilization from other tissues) that can influence its actual concentration in milk. To confirm this hypothesis, future works in this field will be necessary.

When we examined the concentrations of these minerals by milk output on day 14 of lactation, we observed that all minerals were similar in quantities between the groups, except for $\mathrm{Cl}$ and $\mathrm{Se}$, which presented higher levels in EFG compared to PFG. This also corresponds to the adequate level of circulating minerals we found in the mothers, with the exception of $\mathrm{P}$ and $\mathrm{Fe}$ that were reduced (Table V).

Some minerals have been implicated in the development of the neonate, and several 
complications in newborns, such as deficiency in the growth and intellectual development that have been associated with the deficiency of iron, copper and zinc (Haschke et al., 1995; Costa et al., 2002).

In the rat during suckling, hepatic stores that were accumulated in the uterus are a substantial source of minerals, mostly $\mathrm{Cu}^{+2}$, for neonates (Keen et al., 1981). This study has revealed lower concentration of $\mathrm{Cu}^{+2}$ in the plasma of suckling pups from ethanoltreated mothers (Table V), while the mineral concentrations in the liver do not differ between the groups (Table VI). Burmistrov and Borodkin (1990) and Jacques et al. (1989) also observed that serum copper levels decrease with alcohol intake. Since $\mathrm{Cu}^{+2}$ or ceruloplasmin is progressively unloaded from the liver and released into the blood during neonatal development (Prohaska, 1990) and we have not observed a decrease of $\mathrm{Cu}^{+2}$ in liver in the present study, it is possible that ethanol alters the pattern of $\mathrm{Cu}^{+2}$ (or cerulosplasmin) release into the blood. The lower levels of $\mathrm{Cu}^{+2}$ in plasma of pups from EFG could also be attributed to an inability to synthesize the protein cerulosplasmin rather than to a lack of available $\mathrm{Cu}^{+2}$, since a high percentage of the copper circulating in plasma is bound to this protein (Hambidge, 2003). This hypothesis agrees with the observation that ethanol treatment decreased hepatic synthesis and the secretion of proteins.

The present study also showed that the brains of the litters of ethanol-treated mothers presented lower concentrations of $\mathrm{Ca}$ and $\mathrm{Cl}$, and higher concentration of $\mathrm{Cd}$. It is known that brain cells, particularly neurons, are highly dependent on proper amounts of available sodium, potassium, chloride, and calcium. Therefore any disruption in the proper flow and availability of these electrolytes alters the functionality of the neurons, leading to modifications both in behavior and in the ability of the brain to regulate other organic processes (Bourre, 2004). On the other hand, cadmium is one of the most toxic heavy metals (Brzóska et al., 2002) and ethanol is able to increase the permeability of biological membranes to various substances, including toxic metals (Pal et $a l ., 1993)$, and was reported to increase $\mathrm{Cd}$ retention in rat brain (Pal et al., 1993; Brzóska et al., 2000). Brzóska et al. (2002) showed that $\mathrm{Cd}$ caused disturbances in $\mathrm{Zn}$ and $\mathrm{Cu}$ metabolism, reflected by changes in these bioelement concentrations and contents in tissues and biological fluids.

All these alterations on brain mineral composition in the EFG pups occur during a sensitive brain development period and may lead to an abnormal development, with permanent effects over life. Therefore, the results of the current study - showing the effects produced by ethanol during lactation on lactating performance and mineral status of pups æ must be taken into account when advising mothers about alcohol intake during lactation.

\section{ACKNOWLEDGEMENTS}

This work was supported by grants from Fundação Universitária José Bonifácio (FUJB), Conselho Nacional de Desenvolvimento Científico e Tecnológico (CNPq), and Fundação de Amparo à Pesquisa Carlos Chagas Filho do Estado do Rio de Janeiro (FAPERJ).

\section{REFERENCES}

ALBUQUERQUE KT, TAVARES DO CARMO MG HERRERA E. 2000. Ethanol Consumption by Lactating Rats Induces Changes in Pup's Fatty Acid Profiles. Nutr. Neurosci. 3: 331-337

BLUME, S. 1987. Beer and breast-feeding mom. J. Amer. Assoc. 15: 21-26

BOURRE JM. 2004. The role of nutritional factors on the structure and function of the brain: an update on dietary requirements. Rev. Neurol. 160 (8-9): 767-792

BRIGHAM HE, SAKANASHI TM, RASMUSSEN KM 1992. The effect of food restriction during the reproductive cycle on organ growth and milk yield and composition in the rat. Nutrition Research 12: 845-856

BRZÓSKA MM, MONIUSZKO-JAKONIUK J, JUECZUK M, GALAZYN-SIDORCZUK M. 2002. Cadmium turnover and changes of zinc and copper body status of rats continuously exposed to cadmium and ethanol. Alcohol and Alcoholism 37(3): 213-221

BRZÓSKA MM, MONIUSZKO-JAKONIUK J, JURCZUK M, GALAZYN-SIDORCZUK M, ROGALSKA J. 2000. Effect of short-term ethanol administration on cadmium retention and bioelements metabolism in rats continuously exposed to cadmium. Alcohol and Alcoholism 35: 439-445

BURGOS, MGPA, BION FM, CAMPOS F. 2004. Lactação 
e álcool: Efeitos clínicos e nutricionais. Archivos Latinoamericanos de Nutricion 54 (1): 25-35

BURMISTROV SO, BORODKIN IUS. 1990. The characteristics of the enzyme status of the antioxidant protection and the level of lipid peroxidation in the brain tissue and blood of rats with differing preferences for ethanol. Farmakol. Toksikol. 53(5): 59-60

COSTA RS, TAVARES DO CARMO MG, SAUNDERS C, LOPES RT, DE JESUS EF, SIMABUCO SM. 2002. Trace elements content of colostrum milk in Brazil. Journal of Food Composition and Analysis 15: 27-33

DUBOIS M, GILLES KA, HAMILTON J, REBERS PA, SMITH F. 1956. Colorimetric method for determination of sugars and related substances. Analytical Chemistry 28(3): 350-556

FAAS AE, SPONTÓN ED, MOYA PR, MOLINA JC. 2000. Differential responsiveness to alcohol odor in human neonates: effects of maternal consumption during gestation. Alcohol 22: 7-17

FUENTES LM, ARTILLO R, CARRERAS O. 2001 Effects of maternal chronic ethanol administration in the rat: lactation performance and pup's growth. European Journal Nutrition 40: 147-154

GENZEL-BOROVICZÉNY O, WAHLE J, KOLETZKO B. 1997. Fatty acid composition of human milk during the 1 st month after term and preterm delivery Eur. J. Pediatr. 156(2): 142-147

GODBOLE VY, GRUNDLEGER ML, PASQUIME, TA, THENEN SW. 1981. Composition of rat milk from day 5 to 20 of lactation and milk intake of lean and preobese Zucker pups. J. Nutr. 111: 480-487

GUERRI C, SANCHIS R. 1986. Alcohol and acetaldeyde in rat's milk folowing administration. Life Sciences 38(17): 1543-1556

HAMBIDGE M. 2003. Biomarkers of Trace Mineral Intake and Status. J. Nutr. 133: 948S-955S

HASCHKE F, HUEMER C, PIETSCHNIG B. 1995. Trace element deficiencies. In: Clinical Nutrition on the Young Child. Nestec Ltd Vevey, Raven Press, New York, p. 547-560

HEIL SH, HUNGUND BL, ZHENG ZH, JEN KLC, SUBRAMANIAN MG. 1998. Ethanol and lactation: Effects on milk lipids and serum constituents. Alcohol 18: $43-48$

HEIL SH, SUBRAMANIAN MG. 2000. Chronic alcohol exposure and lactation: Extended observations. Alcohol 21(2): $127-132$

HERRERA E. 1981. Ethanol toxicity: Metabolic effects and experimental model for the "fetal alcohol syndrome". General Pharmacology: The Vascular System 12 (2): A17

JACQUES PF, SULSKY S, HARTZ SC, RUSSEL RM. 1989. Moderate alcohol intake and nutritional status in nonalcoholic elderly subjects. Am. J. Clin. Nutr. 50: 875-883

JONES PJ, LEICHTER J, LEE M. 1981. Placental blood flow in rats fed alcohol before and during gestation. Life Sci. 29(11): 1153-9

KEEN CL, LONNERDAL B, CLEGG M, HURLEY L. 1981. Developmental changes in composition of rat milk: trace elements, minerals protein, carbohydrate and fat. Journal of Nutrition 111 (2): 226-230

KESANIEMI YA. Ethanol and acetaldehyde in the milk and peripheral blood of lactating women after ethanol administration. 1974. J Obstet Gynaecol Br Commonw 81(1): 84-6

KLOCKENKÄMPER R. 1992. Total reflection x-ray fluorescence spectroscopy. Analytical Chemistry 64, $1115 \mathrm{~A}$

LEPAGE G, ROY CC. 1986. Direct transesterification of all classes of lipid in one-step reaction. J. Lip. Res. 27: 114- 120

LIMA LA, MELO-JUNIOR MR, CAVALCANTI CLB, MELO CB, PONTES-FILHO NT. 2002 Does the exposition to alcohol in pre and post-natal periods interfere on the formation and maturation of Peyers Patches? An. Fac. Med. UFPE 47(1): 22-26

LOWRY OH, ROSEBROUGHT NJ, FARR AL, RANDALL RJ. 1951. Protein measurement with the Folin-Phenol reagent. J. Biol. Chem. 193: 265-275

MARQUIS SM, LEICTER J, LEE M. 1984. Plasma amino acids and glucose levels in the rat fetus and dam after chronic maternal alcohol consumption. Biol Neonate. 46(1): 36-43

MARSZALEK JR, LODISH HF. 2005. Docosahexaenoic acid, fatty acid-interacting proteins, and neuronal function: Breastmilk and Fish Are Good for You. Ann. Rev. Cell. Dev. Biol. 21: 633-657

MENNELLA JA. 1997. Infant's suckling responses to the flavor of alcohol in mother's milk. Alcohol Clin Exp Res 21: 581-5

MENNELLA JA, BEAUCHAMP K. 1993. Effects of beer on breast-fed. J. Amer. Med. Assoc. 269: 1673-1678

MENNELLA JA, PEPINO MY, TEFF KL. 2005 Acute alcohol consumption disrupts the hormonal milieu of lactating women. J. Clin. Endocrinol. Metab. 90(4): 1979-1985

MOLINA JC, SPEAR NE, SPEAR LP, MENNELLA JA, LEWIS MJ. 2007. Alcohol and development: Beyond Fetal Alcohol Syndrome. Dev Psychobiol 49: 227-42

NERVI AM, PELUFFO RO, BRENNER RR, LEIKEN AI. 1980 Effect of ethanol administration on fatty acid desaturation. Lipids 15, 263-268

NEVILLE MC, PICCIANO MF. 1997. Regulation of milk lipid secretion and composition. Ann. Rev. Nutr. 17: 159-184

OYAMA LM; OLLER DO NASCIMENTO CM. 2003. Effect of ethanol intake during lactation on male and female pups' liver and brain metabolism during the suckling-weaning transition period. Nutr. Neurosci. 6(3): 183-188

PAL R, NATH, R, GILL, KD. 1993. Influence of ethanol on cadmium accumulation and its impact on lipid peroxidation and membrane bound functional enzymes $\left(\mathrm{Na}^{+}, \mathrm{K}^{+}\right.$-ATPase and acetylcholinesterase) in various regions of adult rat brain. Neurochemical Investigation 23: 451-458

PERES WAF, TAVARES DO CARMO MG, IGLESIAS AC, ZUCOLOTO S, BRAULIO V. 2004. Ethanol intake inhibits growth of the epithelium in the intestine of pregnant rats. Alcohol 1: 5-9

PROHASKA JR. 1990. Development of copper deficiency in neonatal mice. J. Nutr. Biochem. 1: 415-419

PUETA M, ABATE P, HAYMAL OB, SPEAR NE, MOLINA JC. 2008. Ethanol exposure during late gestation and nursing in the rat: Effects upon maternal care, ethanol metabolism and infantile milk intake. Pharmacol Biochem Behav (2008), doi: 10.1016/ j.pbb.2008.06.007 (in press)

REEVES PG, NIELSEN FH, FAHEY GC. 1993. AIN-93 Purified diets for laboratory rodents: final report of the American institute of nutrition ad hoc writing committee on the reformulation of the AIN-75A rodent diet. American Institute of Nutrition 22: 31663193

SAMPSON, DA, JANSEN, GR. 1984. Measurement of milk yield in the lactating rat from pup weight and weight gain. J. Pediatr. Gastroenterol. Nutr. 3: 613-617

SANCHIS R, SANCHO-TELLO M, GUERRI C. 1989. The role of liquid diet formulation in the postnatal ethanol 
exposure of rats via mother's milk. J. Nutr. 119(1): 8288

SUBRAMANIAN MG. 1999. Alcohol inhibits sucklinginduced oxytocin release in the lactating rat. Alcohol 1: 51-55

SUMIDA KD, COGGER AA, MATVEYENKO AV. 2007 Alcohol-induced suppression of gluconeogenesis is greater in ethanol fed female rat hepatocytes than males. Alcohol 41: 67-75

TAVARES DO CARMO MG, OILER DO NASCIMENTO CM, MARTIN A, HERRERA E. 1999. Ethanol intake during lactation impairs milk production in rats and affects growth and metabolism of suckling pups. Alcohol 18(1): 71-76

TAVARES DO CARMO MG, OLLER DO NASCIMENTO CM, MARTIN A, HERRERA E. 1996. Effects of ethanol intake on lipid metabolism in the lactating rat. Alcohol 13(5): 443-448
TESTAR X, LÓPEZ D, LLOBERA M, HERRERA E. 1986. Ethanol administration in the drinking fluid to pregnant rats as a model for the fetal alcohol síndrome. Pharmacol Biochem Behav 24(3): 625-30

TUCKER HA. 1979. Endocrinology of lactation. Semin. Perinatol. 3: 199-223

VILARÓ S, VINAS O, REMESAR X, HERRERA E. 1987. Effects of chronic ethanol consumption on lactational performance in rat: mammary gland and milk composition and pups'growth and metabolism. Pharmacol. Biochem. Behav. 27: 333-339

WHITWORTH NS. 1988. Lactation in humans. Psychoneuroendocrin. 13: 171-188

ZHU X; SEELIG LLJR. 2000. Developmental aspects of intestinal intraepithelial and lamina propria lymphocytes in the rat following placental and lactational exposure to ethanol. Alcohol and Alcoholism 35(1): 25-30. 